\title{
Влияние полиморфизмов генов GSTM и GSTT на скорость восстановления когнитивных функций после введения пропофола
}

\author{
Шашкина Е. ${ }^{1}$, Ушакова А. ${ }^{1}$, Черданцев С.В. ${ }^{1,2}$, Воронина Е.Н. ${ }^{1,2}$ \\ ${ }^{1}$ Специализированный учебно-научный центр Новосибирского государственного университета, \\ Новосибирск, Россия \\ ${ }^{2}$ Региональный центр выявления и поддержки одаренных детей «Альтаир», Новосибирск, Россия \\ *e.shashkina1@school.nsu.ru
}

Ключевые слова: наркоз, глутатион-S-трансфераза мю 1 (GSTM1), глутатион-S-трансфераза тета 1 (GSTT1), наркоз, rt-ПЦР, пропофол

\begin{abstract}
Мотивация и цель: Во время операции врачи чаще всего сталкиваются с ситуациями, когда пациент плохо переносит наркоз, демонстрируя неполное восприятие нервной системой препарата, при котором могут оставаться побочные эффекты: тошнота, головокружение и др. Изучая мутации определенных генов, можно прогнозировать, как именно пациент переносит различные препараты. Это поможет врачам подбирать лекарства индивидуально, избегая последствий «плохого наркоза». Поэтому в нашей проектной работе мы изучали влияние генов, отвечающих за метаболизм и вывод ксенобиотиков в организме человека.

Цель нашего исследования - изучить полиморфизмы генов семейства GST: GSTT и GSTM, у пациентов, которым был введен снотворный препарат - пропофол. Определить влияние на скорость восстановления когнитивных функций.

Meтоды $и$ алгоритмы: Мы использовали метод rt-ПЦР, чтобы определить наличие или делецию генов GSTM и GSTT, результаты ПЦР анализировались с помощью программы BioRad CFX.

Pезультаты: Из выборки в 45 человек мы выделили четыре группы людей: с присутствием обоих генов GSTM и GSTT, с делецией обоих генов GSTM и GSTT, с присутствием одного гена и с присутствием другого.

Заключение: Мы изучили полиморфизмы генов. Исследовали зависимость скорости восстановления когнитивных функций после введения пропофола. Была выявлена зависимость между скоростью восстановления когнитивных функций и генотипом пациента.
\end{abstract}

